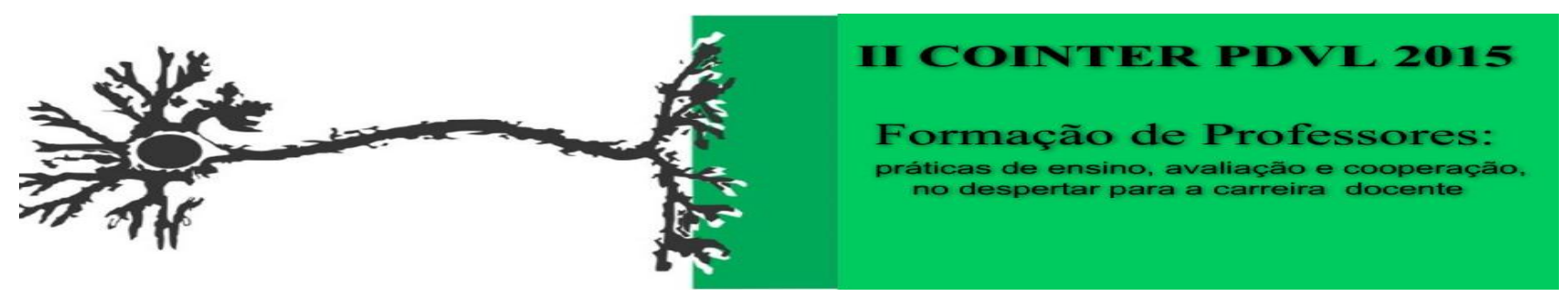

\title{
AS AÇÕES CONSTRUTIVAS DO CONHECIMENTO QUÍMICO NAS ESCOLAS PÚBLICAS E A FORMAÇÃO INICIAL DOS LICENCIANDOS EM QUÍMICA EM ALAGOAS
}

\author{
Apresentação: Relato de Experiência \\ Elié Paula Predi Dornelas de Souza ${ }^{1}$ Jaqueline Quintino da Silva ${ }^{2}$;oacy Vicente Ferreira ${ }^{3}$
}

\section{Introdução}

A Olimpíada Brasileira de Química é um evento de cunho competitivo, que anualmente se inicia no mês de agosto, para estudantes do ensino médio e tecnológico. No Instituto Federal de Alagoas o Projeto Ações Construtivas do Conhecimento Químico nas escolas pública desenvolve práticas que evidenciam a contribuição "para a formação de profissionais na área de Química, com o consequente aumento no número de alunos dos cursos de pós-graduação e do quantitativo de docentes e de pesquisadores nesta área" (OBQUÍMICA.ORG, 2015). Visando o aprofundamento em Química para estudantes de escolas públicas do ensino médio. Tendo em vista a inserção dos graduandos no seu futuro espaço profissional, de modo que esses conheçam a realidade da sala de aula antes mesmo do estágio supervisionado.

\section{Relato de Experiência}

Considerando a formação inicial dos licenciandos em Química, esse projeto evidencia a atuação das aulas desse projeto de extensão. No estado de Alagoas a atividades foram desenvolvidas na Escola Estadual Moreira e Silva destinada a estudantes de $1^{\circ}$ e $2^{\circ}$ anos do ensino médio. O contato inicial com os alunos ocorreu por meio do "show da química", com a realização de experimentos atrativos, e aulas ministradas em dias de sábado. A intervenção didática versava entre aulas teóricas e práticas experimentais, conduzidas por bolsistas. Estimulando nestes, a prática da pesquisa em educação afim de compreender a realidade docente.

A atuação dos licenciandos diante dessa proposta teve um cunho marcante acerca do reconhecimento profissional e, continuidade do curso de licenciatura, uma vez que o contato com a

\footnotetext{
${ }^{1}$ Licenciatura em Química, Instituto Federal de Alagoas, eliepaulap@gmail.com

${ }^{2}$ Licenciatura em Química, Instituto Federal e Alagoas, jaqueline.quintino6@gmail.com

${ }^{3}$ Doutor em Química, Instituto Federal de Alagoas, joacyferreira@ifal.edu.br
} 
sala de aula reafirma o interesse na escolha pela profissão. Para proporcionar uma melhor formação de professores as Universidades Públicas tem investido mais em iniciativas de pesquisa (GATTI, 1997, p. 51). Nessa perspectiva, as contribuições desta proposta sumariza o fazer docente dos participantes, de modo a influenciar positivamente no planejamento de aulas expositivas e experimentais, bem como o contato com a comunidade escolar.

Imagem 1: Realização das atividades na escola. Fonte: Própria

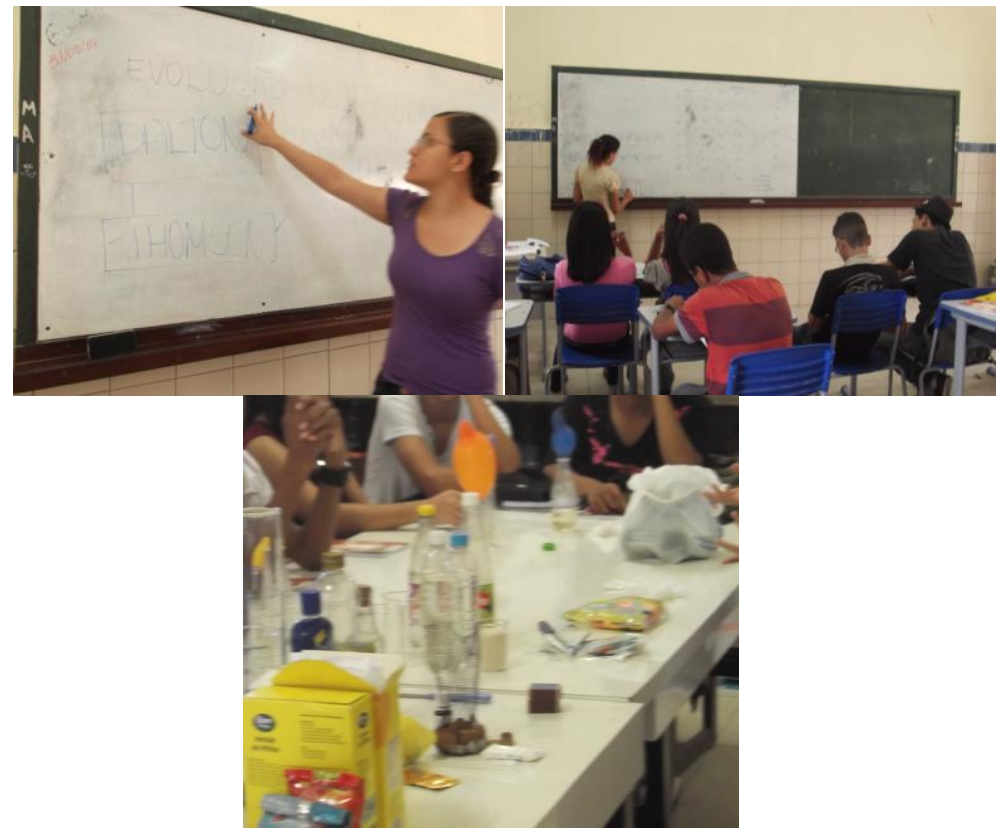

\section{Considerações}

As contribuições desse programa abrangem dois públicos, tanto os estudantes envolvidos, quanto os licenciandos em Química. O caráter formativo leva ao desenvolvimento de habilidades de pesquisa na extensão, em que todos os participantes ganharam experiências positivas para aprendizagem.

\section{Referências}

GATTI, B. A. Formação de professores e carreira: problemas e movimentos de renovação. Campinas: Autores Associados, 1997.

PROGRAMA NACIONAL DAS OLIMPÍADAS BRASILEIRA DE QUÍMICA. - Principal. Disponível em: http://www.obquimica.org/olimpiadas/brasileira. Acesso em: 10/08/15. 